bolism taken in the introductory historical sketch. Here Sir Herbert took the lightning flash and the thunderbolt as the first expression by early man in his 'rude art' of the symbolism of divine power. The gods depicted by man held the symbol of the thunderbolt first as a weapon, later as a baton or sceptre of authority. In that form, Sir Herbert pointed out, it is a widespread symbol in all primitive art. It occurs among Minoans, Greeks, Romans, the Hittites, in Mesopotamia, Central Asia, India and Mexico. The bolt was traced, with the addition of the wings of Jove, as it developed into the trident of Poseidon and Britannia and the lily of France. Two interesting examples of misinterpretation were quoted, which are not without a moral for those who practise interpretation of symbols : first, Napoleon mistook the fleur-de-lys of Clovis for bees and changed the fleur-de-lys in his own arms and those of Paris to representations of that insect; secondly, the Belgians took the flower on the French soldiers' uniform for representations of the frog and christened the French crapauds accordingly.

\section{Sounding the Ionosphere}

Prof. E. V. Appleton showed in our columns in 1931 the importance of determining the variation, with frequency, of the equivalent path traversed by wireless signals returned from the ionosphere, since such determinations measure the maximum density of ionisation in the regions sounded. The letter from Mr. R. Naismith which we publish in our correspondence columns this week describes work which he carried out in May 1933. We understand that publication was deferred in accordance with an agreement between British and German workers that none of the results of radio work within the programme of the Second International Polar Year should be published until after the end of that year. The letter directs attention to the need for a rapid and more or less completely automatic method for recording the relation between the radio frequency of the pulse signals used and the equivalent path traversed by them in their double journey to and from the ionosphere, at nearly vertical incidence. At the time when the work described was carried out, there were available several methods for the continuous automatic recording of equivalent path against time of day, for a single frequency, but not for the more difficult problem of recording path against frequency.

THE radio staff at the U.S. Bureau of Standards has been working on the same problem, and at the annual convention of the Institute of Radio Engineers at Chicago on June 27, 1933, Mr. T. R. Gilliland (Bur. Stds. Jour. Research, Oct. 1933) described an automatic recording system giving records of the required type over the frequency range of 2500 $4400 \mathrm{kc} . / \mathrm{s}$., the frequency being varied at the uniform rate of $200 \mathrm{kc} / \mathrm{s}$. per minute so that the full range was covered in about ten minutes. The closeness of dates between the American and British work is illustrated by the fact that Mr. Gilliland showed a record for April 22, 1933, while Mr. Naismith shows one for June 6 and informs us that his first record was taken on May 20. The means of investigation thus made available is clearly a very powerful one, and geophysicists will look forward to the results of the further developments promised from the Bureau of Standards and the National Physical Laboratory.

\section{Yorkshire Scientific Magazines}

THE publication of the December issue of the Naturalist, the monthly journal of the Yorkshire Naturalists' Union, completes a hundred years of the regular publication of this scientific magazine. The Naturalist originally appeared under the title of the Field Naturalist as an octavo monthly of 48 pages in January 1833, under the editorship of $\mathrm{Mr}$. James Rennie. It ran for fourteen issues and then appeared under the title of the Naturalist, edited by Mr. Neville Wood, of Doncaster. In 1851 the second series of the Naturalist commenced under.the editorship of Beverley R. Morris, and later the Rev. F. C. Morris, author of the well-known "History of British Birds"; the third series, edited by C. P. Hobkirk, appeared from Huddersfield in 1864. The fourth series of this magazine were edited by Joseph Wainwright and appeared from Huddersfield under the changed title of the Yorkshire Naturalists' Recorder, but the fifth series, in August 1865, reverted to the present title, the Naturalist (Sheppard, "Yorkshire's Contribution to Scientific Literature", Naturalist, 1915). The fifth series, edited by Messrs. C. P. Hobkirk and G. T. Pomitt, was issued at Pontefract, but later transferred to Leeds under the editorship of W. D. Roebuck and W. Eagle Clark, in 1884. In 1889, W. Eagle Clark, leaving for Edinburgh Museum, vacated his editorial post and Roebuck continued to be editor until 1912, assisted by E. R. Wade in 1892 . In 1902 the Naturalist was issued from Hull under the editorship of T. Sheppard, assisted by Dr. T. W. Woodward. Mr. Sheppard relinquished the editorship in 1932. He was succeeded in 1933 by Dr. W. E. Pearsall and W. R. Grist as editors, when the Naturalist once more was issued from Leeds.

FEw counties have such an interesting record of scientific journalism as Yorkshire, and the Naturalist has watched many contemporary magazines rise and fall in its century. The Bradford Scientific Journal and the Halifax Naturalist were contemporary magazines. The Circular appeared as a scientific monthly in Halifax, 1866, while the Practical Naturalist commenced in Bradford in 1883 and was continued at Ilkely. The Naturalists' World was another of Ilkely's scientific monthlies and in 1879 the Young Naturalist appeared from Hartlepool and Huddersfield, becoming the British Naturalist in 1891, but ceasing issue in 1894. From 1882 until 1883, the Naturalists' Monthly was issued from Bradford and in 1892, the Naturalists' Journal commenced, later becoming Nature Study and being issued from Huddersfield, where it ceased publication in 1905 . The New Nature Study commenced at Huddersfield in 1912 but was short lived. The Malton Field Naturalists' Society issued a monthly journal, 
Naturalists' Notes, at the end of last century, while the Natural History Journal was published at York from 1877 until 1898. A contemporary, the Naturalist, but with no connexion with the present journal of that name, appeared monthly in York in 1834, mainly for school nature students.

\section{Conference of Educational Associations}

THE twenty-second annual Conference of Educational Associations was held at University College, London, on January 1-8. Dr. George Dyson, of Winchester College, in his presidential address on "Education for Life", said that though there is a great and growing interest in music and the arts, it is still true that the writing of poems, the making of pictures, the modelling of statues, the playing of sonatas, the composition of songs, are regarded as frills. Our education is a system of mental education, training only a fraction of human faculty and character. He recommended a system of differentiated secondary schools, one type being frankly a workshop.

The Great Hall was crowded on January 4 for a discussion on "The Failure of Modern Science to develop an Adequate Cultural Background to Life". Dr. W. W. Vaughan presided and the discussion was opened by Prof. Julian Huxley, who said that the defects of scientific education are over-specialisation, the failure to link science to other studies and over-emphasis on physics and chemistry, as against biology and related subjects. There is a tendency to devote too much time to practical work. He considers that science should be studied as an integral part of history and that more attention should be given to applied science, the aims of science teaching being a coherent general outlook in which scientific ideas are integrated, and the inculcation of the scientific method in human affairs. Sir Arnold Wilson's contribution to the discussion showed that he favours the teaching of science in elementary schools, in which he thinks there should be great development, and he stressed the ethical aspect of science teaching and its hope of bringing inspiration, strength and inward peace to mankind and stability to civilisation. The subsequent discussion elicited several useful suggestions, one being that young and rapidly developing branches of science might be considered from the viewpoint of their educational value. Several speakers referred to the importance of personal influences, the use of leisure, and emotional life and experience as contributing to 'cultural background'.

\section{Association of British Zoologists}

THE annual meeting of the Association of British Zoologists was held in the rooms of the Zoological Society in Regent's Park on January 6. On previous occasions the Association has been interested in the provision of revision classes in biology at the universities for school teachers. Dr. F. A. Dixey reported the work which the Council of the Association has done in the past year on this subject. Classes are now provided at several universities and have been well attended. In view of the expansion in the teaching of biology in schools which is now taking place, the subject is recognised as important, and the Council was asked to continue its activities. Mrs. M. D. Brindley, opened a discussion on the possibility of providing some means by which information concerning the British fauna could be made more easily and rapidly accessible. The preservation of the fauna among the rapid and widespread changes which are bound to occur in a thickly populated country is difficult, but it is a task in which zoologists must always be interested. Changes in the fauna are often of importance to the community. At present a very large amount of information on the natural history of the fauna has been collected but much of it is seattered through many, often obscure, journals.

Prof. D. M. S. Watson gave his views of the scope of the teaching which should be carried on in a university department of zoology. In order that the student may be able to deal later with the biological problems which will be the subject of his investigations, his teaching should be broad and should be concerned as much with the natural history and physiology of animals as with their structure. Prof. Watson gave an account of the way in which these views have been expressed in the design of the buildings which have recently been built for his department at University College. Some problems of zoological technique were also discussed. Prof. H. G. Cannon gave a lecture on the technique of making drawings for the illustration of zoological papers. It is hoped that the Council will be able to publish his lecture.

\section{Ninth International Congress of Pure and Applied Chemistry}

SPAIN will act as host for the ninth International Congress of Pure and Applied Chemistry, which will be held in Madrid on April 5-11, 1934, under the patronage of H.E. the President of the Spanish Republic and of the Spanish Government. The object of the Congress, which was to have been held in 1932, is to promote the progress of pure and applied chemistry, and to strengthen relations between chemists throughout the world. The president of the bureau of the Congress is Prof. Obdulio Fernández, and the general secretary is Prof. Enrique Moles; the address of the organising committee's office is San Bernardo 49 (P.O. Box 8043), Madrid (8). Membership is of three categories : honorary members, comprising the committees of honour and of patronage, and the official delegates of the Spanish Government and of the governments of other countries; supporting members, who pay the minimum amount of 300 pesetas; and active members, who pay a fee of 75 pesetas (about $£ 117 s .6 d$.). Members' ladies pay 25 pesetas only, but they will not be entitled, as members are, to receive publications in extenso, the daily bulletin, summaries of communications, or the report of proceedings. Membership is open to societies, institutions, etc., connected with any branch of pure or applied chemistry, and to individuals interested therein. Applications for membership should be made to the general secretary before February 15, 1934, and should be accompanied by a remittance 